\title{
Chemical Synthesis and Hemi-Synthesis of Novel Benzimidazole Derivatives Using Microwave-Assisted Process: Chemical Characterization, Bioactivities and Molecular Docking ${ }^{+}$
}

\author{
Asmaâ Sameut ${ }^{1,2}$, Sarah Yasmine Zanndouche ${ }^{1,3}$, Chaimaa Boumaza ${ }^{1,2}$, Chaima Dikes ${ }^{1,3}$ and \\ Borhane Eddine Cherif Ziani ${ }^{1, *}$ \\ 1 Centre de Recherche Scientifique et Technique en Analyses Physico-Chimiques CRAPC, \\ Bouismail 42002, Algeria; sameutasmaa@yahoo.com (A.S.); sarahyasminezd@gmail.com (S.Y.Z.); \\ chaimaaboumaza1997@gmail.com (C.B.); chaimaa130@gmail.com (C.D.); \\ 2 Department of Biology, University of Sâad Dahleb Bilda, Bilda 9000, Algeria \\ 3 Department of Biology, University of Science and Technology Houari Boumediene, Algiers 16000, Algeria \\ * Correspondence: ziani.borhane@crapc.dz; Tel.: +213-673-954-968 \\ + Presented at the 24th International Electronic Conference on Synthetic Organic Chemistry, \\ 15 November-15 December 2020; Available online: https://ecsoc-24.sciforum.net/.
}

Citation: Sameut, A.; Zanndouche, Y.S.; Boumaza, C.; Dikes, C.; Ziani, B.E.C. Chemical Synthesis and Hemi-Synthesis of Novel Benzimidazoles Derivatives Using Microwave-Assisted Process: Chemical Characterization, Bioactivities and Molecular Docking. Chem. Proc. 2021, 3, 71. https:// doi.org/10.3390/ecsoc-24-08306

Academic Editors: Julio A. Seijas and M. Pilar Vázquez-Tato

Published: 14 November 2020

Publisher's Note: MDPI stays neutral with regard to jurisdictional claims in published maps and institutional affiliations.

Copyright: @ 2020 by the authors. Licensee MDPI, Basel, Switzerland. This article is an open access article distributed under the terms and conditions of the Creative Commons Attribution (CC BY) license (http://creativecommons.org/licenses/by/4.0/).

\begin{abstract}
Benzimidazole derivatives represent a class of heterocyclic compounds that exhibit a wide range of pharmaceutical properties. The present study aimed to investigate the in-vitro antioxidant and antimicrobial activities of newly synthesized benzimidazole derivatives. Compound $\mathbf{1 b}(2-(1 \mathrm{H}-$ 1,3-benzodiazol-2-yl) phenol) was synthesized by reacting o-phenylenediamine (OPA) with chemical salicylaldehyde, while compounds $\mathbf{2 b}$ (2-(2-[(1E)-2-phenylethenyl]-1H-1,3-benzodiazole) and $\mathbf{3 b}$ (2-[(1E)-2,6-dimethylhepta-1,5-dien-1-yl]-1H-1,3-benzodiazole) were obtained through a hemi-synthesis process of, respectively, the cinnamon (cinnamaldehyde, 90.54\%) and lemongrass (cis-citral, $43.9 \%$ ) essential oils previously characterized by GC/MS. Compounds $4 \mathbf{b}$ (2-phenyl-1H-benzimidazole) and 5b (5-(1H-benzimidazol-2-yl)benzene-1,2,3-triol) were synthesized with a click chemistry method by reacting the OPA with benzoic acid and gallic acid directly in ethanol under microwave irradiation (MW) at $400 \mathrm{MHz}$. The structure/purity of the synthesized compounds was clarified by spectroscopy, ATR-FTIR and NMR ${ }^{1} \mathrm{H}$. Compounds $\mathbf{1} \mathbf{b}-\mathbf{5} \mathbf{b}$ were screened for their antioxidant activity by using four complementary in-vitro assays: DPPH scavenging activity, ferric ion reducing power, $\beta$-carotene bleaching inhibition, and Thiobarbituric Acid Reactive Substance Assay (TBARS) formation inhibition. All the tested compounds showed antioxidant potential, with varying performance. Antimicrobial activity was investigated against American Type Culture Collection (ATCC) strains (three Gram- bacteria: Escherichia coli, Salmonella typhi, and Pseudomonas aeruginosa; one Gram+ bacteria: Staphylococcus aureus, and one yeast strain: Candida albicans) through the determination of the Minimum Inhibitory Concentration (MIC) and the Minimum Bactericidal Concentration (MBC) by using the microdilution method and rapid colorimetric test of p-iodonitrotetrazolium chloride (INT). Compound $5 \mathbf{b}$ exhibited the highest potential, especially against $S$. aureus $\left(\mathrm{MIC}=0.156 \mathrm{mg} \cdot \mathrm{mL}^{-1}\right.$ ) followed by $S$. typhi and C. albicans $\left(\mathrm{MIC}=0.3125 \mathrm{mg} \cdot \mathrm{mL}^{-1}\right.$ ) and then by E. coli and P. aeruginosa. Compound $\mathbf{1 b}$ also showed great potential against $S$. aureus and C. albicans (MIC $\left.<0.3125 \mathrm{mg} \cdot \mathrm{mL}^{-1}\right)$, followed by E. coli and S. typhi $\left(\mathrm{MIC}=0.3125 \mathrm{mg} \cdot \mathrm{mL}^{-1}\right)$ and $P$. aeruginosa $\left(\mathrm{MIC}=0.625 \mathrm{mg} \cdot \mathrm{mL}^{-1}\right)$. Further molecular docking was conducted using AutoDock Vina 1.1.2 software on S. aureus thymidylate kinase (TMK) protein to highlight the structure-activity relationship of the potent molecules.
\end{abstract}

Keywords: benzimidazoles; synthesis; hemi-synthesis; microwave-assisted; NMR ${ }^{1} \mathrm{H}$; antioxidant activity; antimicrobial activity; in-silico docking 


\section{Introduction}

The search for novel antimicrobial compounds in clinical microbiology is prompted by the need to counteract the growing number of infectious diseases caused by multidrugresistant strains (MDR: multidrug-resistant and TDR: totally drug-resistant) [1]. Bacterial resistance has dramatically reduced the effectiveness of the majority of treatments available today, and an increasing number of diseases have become more difficult to treat. Hence, there is an urgent need to develop new therapeutic agents and broad-spectrum pharmaceutical probes for clinical trials [2]. Natural biomolecules of vegetable origin, due to their chemical diversity, such as phenolic acids and chiral monoterpene aldehydes, offer unlimited possibilities for new drug discovery through organic synthesis patterns. These structurally assorted compounds may offer biological potentialities, such as the antioxidant $[3,4]$ and the antimicrobial properties [5] slightly linked to their structure configuration. Moreover, they are good candidates for the hemi-synthesis of new bioactive agents targeting a particular biological activity or protein functionality. Benzimidazoles are heterocyclic compounds that represent, with their derivatives, an interesting class of molecules of great importance in medicinal chemistry, due to the broad diversity of biological properties that they may present (antibacterial, antiviral, antioxidant, anticancer, anti-inflammatory, etc.) [6]. Recently, in-silico docking has seen great advances in predicting the molecular interactions that hold a protein and ligand in the binding site, stimulating the progress of new drug development $[7,8]$. The docking of small molecules and the virtual screening of candidate compounds have become integral in the biomedical field and in drug design. Several software programs have been developed to provide a procedure to predict the interaction of small molecules with protein targets and incorporate flexibility within docking algorithms, such as the AutoDock 4.2 [9] and AutoDock vina 1.1.2 [10] programs.

In this study, we contributed to perform:

- A chemical synthesis and hemi-synthesis of new benzimidazole derivatives;

- A physicochemical characterization (purification and structural analysis) of the synthesized compounds by ${ }^{1} \mathrm{H}$ NMR spectroscopy and FTIR;

- Evaluation of antioxidant and antimicrobial activities by in-vitro assays;

- Evaluation of docking scores of the synthesized compounds on 4QGH (PDB: Protein data base entry) protein of Staphylococcus aureus thymidylate kinase (TMK).

\section{Methods}

\subsection{Plant Material and Extraction Procedure}

Lemongrass (Cymbopogon citratus L.) plant was collected from Tipaza province, Algeria, while cinnamon (Cinnamomum verum L.) bark strips were obtained from a local market in the downtown city of Tipaza. The extraction of essential oils was performed by the hydrodistillation method using a Clevenger-type apparatus [11]. Then, $100 \mathrm{~g}$ of vegetal material was steamed in $500 \mathrm{~mL}$ of boiled water for three hours. After evaporation, the EO was condensed and collected in a shaded bottle (vial) after elimination of water.

\subsection{Essential Oil Analysis}

The components of the extracted essential oils were analyzed by gas chromatography/mass spectrometry (GC/MS) using a Hewlett Packard-6890 system, equipped with a HP-5MS capillary column $(30 \mathrm{~m} \times 0.25 \mathrm{~mm} \times 0.25 \mu \mathrm{m})$ directly coupled to a selective mass detector, Hewllet Packard-5973. Helium was used as the carrier gas $(1 \mathrm{~mL} / \mathrm{min})$. The analysis was performed using the following temperature program: $60-300^{\circ} \mathrm{C}$ to $3^{\circ} \mathrm{C} / \mathrm{min}$; without division for $1.50 \mathrm{~min}$; with a sample volume of $2 \mu \mathrm{L}$ of essential oil solution. The injector and detector temperatures were set at $240^{\circ} \mathrm{C}$. The ion source temperature was 180 ${ }^{\circ} \mathrm{C}$, and mass spectra were obtained in electron ionization mass spectral (EIMS) at $70 \mathrm{eV}$ electron energy. Identification of compounds was based on a comparison of the mass spectra of each peak with those recorded in the MS library (NIST02 and Wiley7) and comparing retention indices and mass spectra with literature data. 


\subsection{Synthesis Procedure}

\subsubsection{Synthesis/Hemi-Synthesis of Three Benzimidazole Aldehyde Derivatives}

The amino derivative 1,2-phenylenediamine (OPA) was first diluted in ethanol (15 $\mathrm{mL}$ ) to form an initial solution of reagent 1 , and then the chemical salicylaldehyde (1 mmol of the corresponding aldehyde, calculated on the basis of its corresponding molecular mass (approximately $0.5 \mathrm{~mL}$ ), was added to an ethanolic solution with a few drops of $\mathrm{HCl}$ $0.05 \%$. For hemi-synthesis, the initial solution was mixed with EO $1 \mathrm{mmol}$ of cinnamaldehyde ( $\sim 90 \%)$ and citral ( 44\%), calculated on the basis of their percentage in the EO under constant agitation at room temperature, and a few drops of $\mathrm{HCl} 0.05 \%$ were added (Figure 1 ). The reaction was left for reflux $(1 \mathrm{~h})$ under an adapted microwave extractor at $400 \mathrm{MHz}$. The crystals of compounds $\mathbf{1 b}, \mathbf{2} \mathbf{b}$ and $\mathbf{3 b}$ were gradually formed in the reaction medium. The precipitates were filtered and washed with cold ethanol after the required time and then purified by thin-layer chromatography (TLC) and column chromatography.
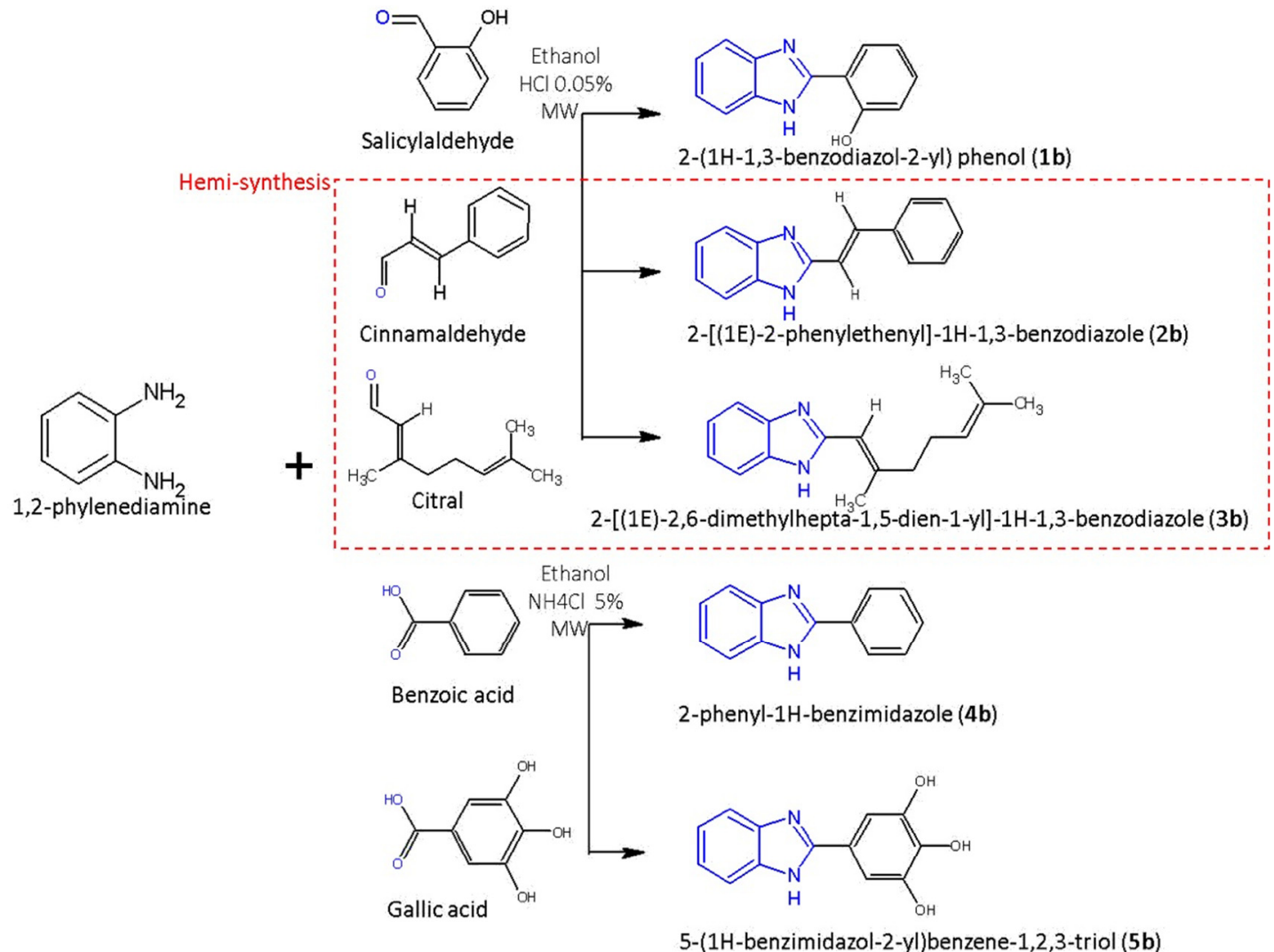

Figure 1. Synthesis procedure and chemical structure of synthesized molecules obtained by ChemSketch software.

\subsubsection{Synthesis of Benzimidazole Phenolic Acid Derivatives}

The total chemical synthesis reaction was carried out by the condensation of OPA with the appropriate phenolic acids $(0.03 \mathrm{~mol})$. The reaction was initiated under microwave irradiation conditions at $400 \mathrm{MHz}$ (Figure 1). Initially, the OPA (3.24 g, 0.03 mole) was dissolved in ethanol in the presence of a few drops of $\mathrm{NH}_{4} \mathrm{Cl}(5 \%)$ in a glass recipient (microwave synthesis reactor) of $30 \mathrm{~mL}$ at room temperature until completely dissolved to form solution 1. After this, each phenolic acid (in molar correspondence) was also dissolved in ethanol $(30 \mathrm{~mL})$ in the reactor and heated to $140{ }^{\circ} \mathrm{C}$ under 10 bars of internal pressure for $5 \mathrm{~min}$. Then, it was cooled to room temperature; thus, solution 2 was formed. The two solutions were mixed and left to react under microwave irradiation at $400 \mathrm{MHz}$ for $10 \mathrm{~min}$ to obtain a precipitate of 2-(4-phenyl substituted)-1H-benzimidazoles. After cooling at room temperature, the precipitated product was washed with cold dichloromethane or hexane, dried to room temperature, and recrystallized in ethanol. 


\subsection{Fractionating/Purification}

To determine the migration patterns of all the synthetized compounds, thin-layer chromatography (TLC) was performed on a thin plate of silica GF-254 with fluorescein developer deposited on a support and visualized under UV at 254/360 nm. The samples were diluted in ethanol and deposited on the bottom of the silica plate by spots. The plate was placed in a vessel containing the migration solvent, allowing the solvent to run to the top edge of the plate. The migration solvent was a mixture of hexane, dichloromethane and ethanol $(2: 6: 2 v / v / v)$. After migration, the chromatography plate was then read directly under UV light; the spots appeared without having to resort to a developer. Afterward, column chromatography was performed to separate and purify the final products of the hemi-synthesized molecules since the reaction may have occurred also on other aldehydes of the EO mixture. The separation was carried out by gravity on silica particles of 70 to $200 \mathrm{~nm}$, where the solvent flowed by drip. The eluent (mobile phase) used here was initially dichloromethane/hexane (50:50 v/v), which allowed the elution of the nonpolar fraction, followed by ethanol and chloroform, which separated the fraction strongly retained by silica. The benzimidazole molecules produced were driven by the mobile phase, and they were recovered in $250 \mathrm{~mL}$ beakers to be dried under vacuum $\left(45^{\circ} \mathrm{C}\right)$.

\subsection{Structural Analysis}

The structural analysis was first monitored by infrared spectroscopy (ATR-FTIR) to determine the functional groups of the purified molecules. The spectra were recorded in a few minutes without any limitation concerning the size of the studied molecule. FTIR spectroscopy in the $4 \times 10^{3} \mathrm{e} 400 \mathrm{~cm}^{-1}$ region was also used to measure trends and reaction patterns in real time, providing very specific information on the kinetics, mechanisms, reaction path and influence of variables on reaction performance. A ${ }^{1} \mathrm{H}$ NMR analysis was then performed on a Bruker 400 spectrometer (Bruker, Wissembourg, France, $400 \mathrm{MHz}$ for $1 \mathrm{H})$, in DMSO- $d_{6}$ as solvent. Chemical shifts $(\delta)$ were reported in ppm and coupling constants $(J)$ in $\mathrm{Hz}$ and the internal standard was Tetramethylsilane (TMS). In a 5-mmdiameter NMR tube, $500 \mathrm{uL}$ of sample (synthetic molecules or standard solution) was inserted and a capillary tube containing a solution of 3-trimethylsilyl-2,2,3,3-d4-propionic acid (TSP-d4) was dosed at $2.1 \mathrm{mmol}$ proton/L. This solution served as a reference for chemical displacement. Depending on the concentration of the samples, 64 to 128 accumulations were made over a spectral width of $3200 \mathrm{~Hz}$. Brüker's Topspin 2.6 NMR software was used for data processing. Structural drawing and naming attribution were monitored by Chemketch software and NMR spectra were processed by the MestRnova 14.2.0 software. Brüker's Topspin CMC 2.6 was used for structure authentication.

\subsection{Bioactivities Properties Evaluation}

\subsubsection{Antioxidant Activity}

The antioxidant activity of the synthesized benzimidazoles was evaluated using four complementary in-vitro tests: DPPH radical scavenging, reducing power (RP), inhibition of $\beta$-carotene bleaching/linoleate, and inhibition of lipid peroxidation in ovine brain cell homogenates (TBARS). The molecules were dissolved in ethanol with a well-known volume to set an initial concentration $\left[\mathrm{C}=3 \mathrm{mg} \cdot \mathrm{mL}^{-1}\right]$ that was diluted at different concentrations until EC50 was determined (concentration providing 50\% antioxidant activity or 0.5 absorbance in the reductive power; expressed in $\mu \mathrm{g} / \mathrm{mL}$ ) [12]. DPPH radical scavenging and RP activity was measured using an ELX800 microplate reader (Bio-Tek Instruments, Inc.; Winooski, VT, USA) at 515 and $690 \mathrm{~nm}$, respectively, and calculated as the percentage of reagent discoloration. Inhibition of $\beta$-carotene bleaching was evaluated by the neutralization levels of linoleate-free radicals that avoided $\beta$-carotene bleaching. Lipid peroxidation inhibition in ovine brain homogenates was evaluated by the decrease in thiobarbitu- 
ric acid reactive substances (TBARS); the color intensity of the malondialdehyde-thiobarbituric acid (MDA-TBA) was measured by its absorbance at $532 \mathrm{~nm}$. Butylated hydroxytoluene (BHT) and Trolox were used as positive controls.

\subsubsection{Antimicrobial Activity}

The synthesized compounds were tested for their antibacterial activity against ATCC strains (Manassas, VA 20108 USA). Three Gram- bacterial strains: Escherichia coli (ATCC ${ }^{\circledR}$ 10145), Salmonella typhi (ATCC ${ }^{\circledR}$ 19430), and Pseudomonas aeruginosa (GEP ATCC ${ }^{\circledR}$ 10145GFP ${ }^{\mathrm{TM}}$ ); one Gram- strain: Staphylococcus aureus (ATCC ${ }^{\circledR} 10832^{\mathrm{TM}}$ ); and one yeast strain: Candida albicans (ATCC ${ }^{\circledR}$ 90819 ${ }^{\mathrm{TM}}$ ). The Minimum Inhibitory Concentration (MIC) and the Minimum Bactericidal Concentration (MBC) values were determined by a microdilution method and a rapid colorimetric test of p-iodonitrotetrazolium chloride (INT) [2]. Briefly, stock solutions of $100 \mathrm{mg} \cdot \mathrm{mL}^{-1}$ were prepared for each compound $(\mathbf{1} \mathbf{b}-\mathbf{5 b})$ in DMSO, and $100 \mu \mathrm{L}$ of each stock solution was diluted in $400 \mu \mathrm{L}$ of MHB (Mueller Hinton broth) or TSB (Tryptone Soy Broth) according to bacterial requirements (resulting in a solution of $\left.20 \mathrm{mg} \cdot \mathrm{mL}^{-1}\right)$. Subsequently, $10 \mu \mathrm{L}$ inoculum $(1.5108 \mathrm{CFU} / \mathrm{mL})$ of fresh bacterial cultures was added to all wells containing tested concentrations in the range of 20-0.156 $\mathrm{mg} \cdot \mathrm{mL}^{-1}$. The microplate was then incubated at $37^{\circ} \mathrm{C}$ for $24 \mathrm{~h}$. The MIC of the sample was determined after addition of INT $\left(0.2 \mathrm{mg} \cdot \mathrm{mL}^{-1}, 20 \mu \mathrm{L}\right)$ and incubation at $37^{\circ} \mathrm{C}$ in an oven (Jouan, Berlin, Germany) for $30 \mathrm{~min}$, where viable microorganisms reduced yellow dye to pink. MIC was defined as the lowest concentration of molecules that prevented this change and allowed complete inhibition of bacterial growth. To determine the minimal bactericidal concentrations (MBC), each negative well and positive control culture (10 $\mu \mathrm{L})$ were sub-cultured into 96-well micro-plates containing culture medium and further incubated at $37^{\circ} \mathrm{C}$ for $24 \mathrm{~h}$. Gentamicine $(10 \mathrm{Ug})$ and Ceftazidime $(30 \mathrm{Ug})$ were used as positive controls for bacterial strains and Nystatine was used for the yeast strain.

\subsection{Molecular Docking Study}

Molecular docking simulations were done using AutoDock Vina software on S. aureus thymidylate kinase (TMK) protein. A crystalized structure of TMK protein (PDB: $4 \mathrm{QGH})$ was selected and obtained from the Protein Data Bank (http://www.rcsb.org/structure/4QGH, accessed on 3 March 2019). The protein was prepared for molecular docking by removing ligand heteroatoms and water molecules and by addition of polar hydrogens on AutoDock tools 1.5.7 software (ADT, The Scripps Research Institute, La Jolla, CA, USA). The ligands $\mathbf{1} \mathbf{b}$ and $\mathbf{5 b}$ were prepared for molecular docking simulation by setting the torsion tree and rotatable, nonrotatable bonds present in the ligand through AutoDock tools 1.5.7 software [13]. The binding scores of the receptor proteins were identified by Biovia DS visualizer. The molecular docking affinity of the receptors/ligands was validated based on the obtained binding energy $(\Delta \mathrm{G})$ and the predicted inhibition constant (Ki).

\section{Results and Discussion}

\subsection{GC/MS Profiles of Essential Oils of Cinnamon and Lemongrass}

The GC/MS profile of cinnamon EO showed variations in the chemical constituents. The GC/MS chromatogram showed that the major compound found throughout the cinnamon oil was cinnamaldehyde at $90.54 \%$ (Table A1, Appendix A). Then, the remaining compounds were minor elements present in very small amounts. Other aldehydes such as benzaldehyde, hydrocinnamaldehyde, and 4-methoxycinnamaldehyde were also detected in very small amounts. However, the descending order of the major compounds present in cinnamon oil as a whole is indicated as follows: -cinnamaldehyde $(90.54 \%)>$ coumarin $(2.87 \%)>$ hydrocinnamaldehyde $(0.92 \%)$. For lemongrass, the oil was dominated by monoterpene hydrocarbons (Table A2, Appendix A). This monoterpenic fraction 
was characterized by a high percentage of cis-citral (43.53\%), neral (34.87\%), and $\beta$-Myrcene $(4.55 \%)$. Other aldehyde components were identified, such as (R)-(+)-citronellal and trans-chrysanthemal, in very low concentrations.

\subsection{Separation and Purification of Synthetic Products}

Qualitative analysis of the fractions obtained by thin-layer chromatography enabled the separation of the fractions and revealed a considerable number of constituents visualized under UV light at 254-360 nm, and the chromatographic profiles and column chromatography were used to separate/fractionate products. First, (2-(1H-1,3-benzodiazol-2yl) phenol) was synthesized by reacting o-phenylenediamine (OPA) with chemical salicylaldehyde, while compounds $\mathbf{2 b}$ (2-[(1E)-2-phenylethenyl]-1H-1,3-benzodiazole) and $\mathbf{3 b}$ (2-[(1E)-2,6-dimethylhepta-1,5-dien-1-yl]-1H-1,3-benzodiazole) were obtained through a hemi-synthesis process of, respectively, the cinnamon (cinnamaldehyde, $90.54 \%$ ) and lemongrass (citral, $43.9 \%$ ) essential oils previously characterized by GC/MS. The reaction of OPA with benzoic and gallic acid gave the benzimidazolic compounds 2-phenyl-1Hbenzimidazole (4b) and 5-(1H-benzimidazol-2-yl)benzene-1,2,3-triol (5b), respectively. In the synthesis reaction, the $1 \mathrm{H}$-benzimidazole heterocycle substituted in position 2 was synthesized by reacting the diamine group of the OPA with the aldehyde function (-COH) of the corresponding aldehyde and the acid function $(-\mathrm{COOH})$ of phenolic acid. These compounds were named using the ChemSketch 12.0 software.

\subsection{Structural Analysis}

The infrared analysis performed by ATR-FTIR spectroscopy informs on functional groups and covalent bonding of the compound produced; it is based on the absorption of light by most of the molecules in the infrared region of the electromagnetic spectrum and by converting this absorption into molecular vibration. This absorption corresponds specifically to the bonds present in the molecule $(\mathrm{N}-\mathrm{H}),(\mathrm{C}-\mathrm{H}),(\mathrm{C}=\mathrm{H}),(\mathrm{C}-\mathrm{H})$ stretching and $(\mathrm{C}-\mathrm{C}-\mathrm{C})$ out of plane bending. The spectra of the most obtained compounds showed significant absorbance rates estimated at around 90\% absorbance between regions 3160 and $3469 \mathrm{~cm}^{-1}$ and $75 \%$ absorbance between regions 1000 and $1500 \mathrm{~cm}^{-1}$, with a specific C-N stretching band at $1368 \mathrm{~cm}^{-1}$ in the benzimidazole ring. On the other hand, the $\mathrm{RMN}^{1} \mathrm{H}$ analysis of the synthetized compounds revealed globally the presence of a $2 \mathrm{H}$ singlet at $8.1,7.6 \mathrm{ppm}$, corresponding to the two pyrrolytic protons. We also noted the presence of a multiplet between 7.16 and $7.08 \mathrm{ppm}$, corresponding to the four aromatic protons. Additionally, two doublets were observed at 7.7 and $7.6 \mathrm{ppm}$, attributable to the four aromatic protons. The chemical shifts in the compounds are represented as follows:

2-(1H-1,3-benzodiazol-2-yl)phenol (1b): ${ }^{1} \mathrm{H}$ NMR, $(400 \mathrm{MHz}$, DMSO-d 6$): \delta 7.12 \mathrm{ppm}(1 \mathrm{H}$, $\mathrm{ddd}, J=7.7,7.5,1.2 \mathrm{~Hz}), 7.23-7.33 \mathrm{ppm}(2 \mathrm{H}, 7.28(\mathrm{ddd}, J=8.1,7.6,1.6 \mathrm{~Hz}), 7.30 \mathrm{ppm}(\mathrm{ddd}$, $J=8.3,1.2,0.4 \mathrm{~Hz})), 7.41 \mathrm{ppm}(1 \mathrm{H}, \mathrm{ddd}, J=7.7,7.6,1.2 \mathrm{~Hz}), 7.54 \mathrm{ppm}(1 \mathrm{H}, \mathrm{ddd}, J=8.3,7.6$, $1.7 \mathrm{~Hz}), 7.72-7.79 \mathrm{ppm}(2 \mathrm{H}, 7.75(\mathrm{ddd}, J=7.7,1.6,0.5 \mathrm{~Hz}), 7.75 \mathrm{ppm}(\mathrm{ddd}, J=7.7,1.7,0.4$ $\mathrm{Hz})), 7.93 \mathrm{ppm}(1 \mathrm{H}, \mathrm{ddd}, J=8.1,1.2,0.5 \mathrm{~Hz})$.

2-[(1E)-2-phenylethenyl]-1H-1,3-benzodiazole (2b): ${ }^{1} \mathrm{H}$ NMR, (400 MHz, DMSO-d6): $\delta 7.05$ $\operatorname{ppm}(1 \mathrm{H}, \mathrm{ddd}, J=7.7,7.6,1.3 \mathrm{~Hz}), 7.10-7.22 \mathrm{ppm}(2 \mathrm{H}, 7.17(\mathrm{~d}, J=14.0 \mathrm{~Hz}), 7.17 \mathrm{ppm}(\mathrm{ddd}$, $J=8.1,7.6,1.4 \mathrm{~Hz})$ ), 7.26-7.46 ppm (6H, 7.36 (dddd, $J=8.0,7.6,1.5,1.5 \mathrm{~Hz}), 7.42 \mathrm{ppm}(\mathrm{d}, J$ $=14.0 \mathrm{~Hz}), 7.41 \mathrm{ppm}(\mathrm{dddd}, J=8.1,1.8,1.5,0.5 \mathrm{~Hz}), 7.31 \mathrm{ppm}(\mathrm{tdd}, J=8.0,1.6,0.5 \mathrm{~Hz})$ ), $7.61 \mathrm{ppm}(1 \mathrm{H}, \mathrm{ddd}, J=8.1,1.3,0.4 \mathrm{~Hz}), 7.86 \mathrm{ppm}(1 \mathrm{H}, \mathrm{ddd}, J=7.7,1.4,0.4 \mathrm{~Hz})$.

2-[(1E)-2,6-dimethylhepta-1,5-dien-1-yl]-1H-1,3-benzodiazole (3b): ${ }^{1} \mathrm{H}$ NMR, $(400 \mathrm{MHz}$, DMSO- $\left.d_{6}\right): \delta 1.53-1.54 \mathrm{ppm}(6 \mathrm{H}, 1.54(\mathrm{~s}), 1.54(\mathrm{~s})), 1.76 \mathrm{ppm}(3 \mathrm{H}, \mathrm{s}), 2.06-2.14 \mathrm{ppm}(4 \mathrm{H}$, $2.12(\mathrm{t}, J=7.4 \mathrm{~Hz}), 2.10 \mathrm{ppm}(\mathrm{td}, J=7.4,7.2 \mathrm{~Hz})), 5.26 \mathrm{ppm}(1 \mathrm{H}, \mathrm{t}, J=7.2 \mathrm{~Hz}), 6.43 \mathrm{ppm}(1 \mathrm{H}$, s), $7.05 \mathrm{ppm}(1 \mathrm{H}, \mathrm{ddd}, J=7.9,7.6,1.3 \mathrm{~Hz}), 7.21 \mathrm{ppm}(1 \mathrm{H}, \mathrm{ddd}, J=8.1,7.6,1.5 \mathrm{~Hz}), 7.58 \mathrm{ppm}$ $(1 \mathrm{H}, \mathrm{ddd}, J=8.1,1.3,0.5 \mathrm{~Hz}), 7.71 \mathrm{ppm}(1 \mathrm{H}, \mathrm{ddd}, J=7.9,1.5,0.5 \mathrm{~Hz})$. 
2-phenyl-1H-benzimidazole (4b): ${ }^{1} \mathrm{H}$ NMR, (400 MHz, DMSO-d6): $\delta 7.05$ ppm $(1 \mathrm{H}, \mathrm{ddd}, J=$ 7.7, 7.6, 1.3 Hz), 7.12-7.22 ppm (2H, $7.17(\mathrm{~d}, J=14.0 \mathrm{~Hz}), 7.17 \mathrm{ppm}(\mathrm{ddd}, J=8.1,7.6,1.4$ $\mathrm{Hz})$ ), 7.26-7.46 ppm (6H, 7.36 (dddd, $J=8.0,7.6,1.5,1.5 \mathrm{~Hz}), 7.42 \mathrm{ppm}(\mathrm{d}, J=14.0 \mathrm{~Hz}), 7.41$ ppm (dddd, $J=8.1,1.8,1.5,0.5 \mathrm{~Hz}), 7.31 \mathrm{ppm}(\mathrm{tdd}, J=8.0,1.6,0.5 \mathrm{~Hz})), 7.61 \mathrm{ppm}(1 \mathrm{H}, \mathrm{ddd}$, $J=8.1,1.3,0.4 \mathrm{~Hz}), 7.86 \mathrm{ppm}(1 \mathrm{H}, \mathrm{ddd}, J=7.7,1.4,0.4 \mathrm{~Hz})$.

5-(1H-benzimidazol-2-yl)benzene-1,2,3-triol (5b): ${ }^{1} \mathrm{H}$ NMR, $\left(400 \mathrm{MHz}, \mathrm{DMSO}-d_{6}\right): \delta 7.06$ ppm $(1 \mathrm{H}, \mathrm{ddd}, J=8.1,6.8,1.4 \mathrm{~Hz}), 7.17 \mathrm{ppm}(2 \mathrm{H}, \mathrm{d}, J=2.4 \mathrm{~Hz}), 7.42 \mathrm{ppm}(1 \mathrm{H}, \mathrm{ddd}, J=8.0,6.8$, $1.3 \mathrm{~Hz}), 7.64 \mathrm{ppm}(1 \mathrm{H}, \mathrm{ddd}, J=8.1,1.3,0.5 \mathrm{~Hz}), 7.87 \mathrm{ppm}(1 \mathrm{H}, \mathrm{ddd}, J=8.0,1.4,0.5 \mathrm{~Hz})$.

\subsection{Bioactivity Properties}

\subsubsection{Antioxidant Activity}

Due to the complexity of oxidation processes and the diverse nature of antioxidants, there is no universal method by which antioxidant activity can be measured quantitatively in a precise manner. Oftentimes, it is necessary to combine the responses of different and complementary tests to obtain an indication of the antioxidant capacity of the sample to be tested [14]. In the present study, the new benzimidazoles reported were screened for their antioxidant activity by using four in vitro assays: DPPH free radical scavenging, reducing power, $\beta$-carotene bleaching inhibition, and TBARS formation inhibition. The results are expressed in EC50 values $(\mu \mathrm{g} / \mathrm{mL})$, as summarized in Table 1 . It is well known that reactive oxygen species (ROS), which can be superoxide radicals, hydroxyl and peroxyl, etc., are causes of oxidative stress, associated with various chronic diseases and DNA damage, leading to carcinogenesis [15]. The six molecules (1)-5b) showed antioxidant activity, with varying performance. Compounds $\mathbf{1 b}$ and $\mathbf{5 b}$ showed the highest activity, with significant EC50s $<200 \mu \mathrm{g} / \mathrm{mL}$, for DPPH and $\beta$-carotene. Compound $\mathbf{3 b}$ showed the highest values for the DPPH test and iron reducing power, respectively, while compound $\mathbf{2 b}$ gave relatively average results. Compound $\mathbf{1 b}$ exhibited the highest potential, very similar to the synthetic antioxidant drug "Trolox" used as a standard for comparison, with EC50 $=53 \mu \mathrm{g} / \mathrm{mL}$ in comparison with Trolox, with an estimated value of $51 \mu \mathrm{g} / \mathrm{mL}$ for the DPPH test. The values obtained for the RP test show that these compounds had a high reducing iron potential, especially of compounds $\mathbf{1 b}$ and $\mathbf{5 b}$ (54 and $96 \mu \mathrm{g} / \mathrm{mL}$ ). Compounds $\mathbf{2 b}$ and $\mathbf{3 b}$ gave also a good result $(101$ and $102 \mu \mathrm{g} / \mathrm{mL})$. The degree of discoloration of $\beta$-carotene was measured by spectrophotometry and used as an estimation of antioxidant activity. Based on the results obtained, compound $\mathbf{5 b}$ appears to be the best inhibitor of linoleic acid oxidation (EC50 = 94 $\mu \mathrm{g} / \mathrm{mL})$, followed by $\mathbf{5 b}(132 \mu \mathrm{g} / \mathrm{mL})$ and $\mathbf{2 b}$ $(181 \mu \mathrm{g} / \mathrm{mL})$. The same observation was made regarding the antiperoxidal activity, where the compounds showed good lipid peroxidation inhibitory activity, for both molecule $\mathbf{5 b}$ $(101 \mu \mathrm{g} / \mathrm{mL})$ and compounds $\mathbf{1 b} / \mathbf{3 b}(\mathrm{EC} 50=134 \mu \mathrm{g} / \mathrm{mL})$. The antioxidant response is herein considered in relation to chemical structure, which determines the redox behavior of the synthesized molecules. It was found that benzimidazole substituted in position 2, containing free hydroxyl groups, which are compounds $\mathbf{1 b}$ and $\mathbf{5} \mathbf{b}$, displaying significant antioxidant activity, including free radical trapping power, iron ion reducing power, and lipid peroxidation inhibiting capacity, which is very remarkable. These are the most promising benzimidazoles for the development of antioxidant drugs.

Table 1. Antioxidant activity.

\begin{tabular}{ccccc}
\hline \multirow{2}{*}{ Synthetized Molecule } & \multicolumn{3}{c}{ Antioxidant Activity EC5O $(\boldsymbol{\mu g} / \mathbf{m L})$} \\
\cline { 2 - 5 } & DPPH Test & Ferric Ion Reducing Power & $\beta$-Carotene & TBARS \\
\hline 1b & $53 \pm 1$ & $54 \pm 4$ & $192 \pm 7$ & $134 \pm 2$ \\
2b & $139 \pm 4$ & $101 \pm 7$ & $181 \pm 5$ & $156 \pm 52$ \\
3b & $220 \pm 15$ & $102 \pm 22$ & $220 \pm 11$ & $134 \pm 2$ \\
4b & $767 \pm 6$ & $544 \pm 4$ & $872 \pm 37$ & $1554 \pm 25$ \\
5b & $78 \pm 5$ & $96 \pm 8$ & $94 \pm 3$ & $101 \pm 7$ \\
BHT & $23 \pm 3$ & $30 \pm 6$ & $48 \pm 5$ & $76 \pm 1$ \\
Trolox & $51 \pm 4$ & $44 \pm 4$ & $63 \pm 2$ & $84 \pm 6$ \\
\hline
\end{tabular}




\subsubsection{Antimicrobial Activity}

The search for new antimicrobial compounds in clinical microbiology is driven by the need to counteract the growing rate of infectious diseases caused by foodborne and/or multidrug-resistant strains (MDR: multidrug-resistant and TDR: totally drug-resistant). Currently, bacterial resistance is leading to a growing need for new and effective antiinfective materials to prevent and delay infections associated with implants and devices. The antibacterial activity of the synthetized molecules $(\mathbf{1} \mathbf{b}-\mathbf{5} \mathbf{b})$ has been tested against four bacterial ATCC strains and one yeast strain. The results are expressed in MIC and MBC values $\left(\mathrm{mg} \cdot \mathrm{mL}^{-1}\right)$, as represented in Table 2 . Results clearly demonstrated different degrees of bacterial growth inhibition. Gram + bacterium S. aureus was more sensitive to the tested molecules, presenting MIC values ranging from 0.156 to $1.25 \mathrm{mg} \cdot \mathrm{mL}^{-1}$ compared with other strains. Compound $\mathbf{5 b}$ was likely the most active compound, presenting an MIC value similar to the standard antibiotic Ceftazidime (MIC $\left.=156 \mathrm{mg} \cdot \mathrm{mL}^{-1}\right)$. According to the chemical characterization, the molecules with hydroxyl groups were the most active (compounds $\mathbf{1 b}$ and $\mathbf{5 b}$ ). These molecules can be considered bactericidal and fungicidal. However, they can be used as antibiotics because of their ability to complex with soluble extracellular proteins and with bacterial cell walls, often resulting in inactivation and loss of function [16]. The antimicrobial activities of products containing hydroxyl groups may involve different modes of action, namely destabilization and permeability of the cytoplasmic membrane and inhibition of enzymes by oxidized products, possibly by reaction with sulfhydryl groups or by more non-specific interactions with proteins [17].

Table 2. Antibacterial activity.

\begin{tabular}{|c|c|c|c|c|c|c|c|c|c|c|}
\hline \multirow{2}{*}{ Synthetized Molecule } & \multicolumn{2}{|c|}{ E. coli } & \multicolumn{2}{|c|}{ S. aureus } & \multicolumn{2}{|c|}{ P. aeruginosa } & \multicolumn{2}{|c|}{ S. typhi } & \multicolumn{2}{|c|}{ C. albicans } \\
\hline & MIC & MBC & MIC & MBC & MIC & MBC & MIC & MBC & MIC & MBC \\
\hline $1 b$ & 0.3125 & 2.5 & $<0.3125$ & 1.25 & 0.625 & 5 & 0.3125 & 5 & $<0.3125$ & 2.5 \\
\hline $2 b$ & 0.3125 & 10 & 0.3125 & 5 & 1.25 & $>10$ & 0.3125 & 5 & 0.625 & 2.5 \\
\hline $3 b$ & 0.3125 & 5 & 0.3125 & 2.5 & 2.5 & 5 & 0.3125 & 5 & 0.3125 & 5 \\
\hline $4 b$ & 2.5 & 2.5 & 1.25 & 1.25 & $>10$ & $>10$ & 2.5 & $>10$ & 5 & $>10$ \\
\hline $5 b$ & 0.625 & 2.5 & 0.156 & 0.625 & 2.5 & 5 & 0.3125 & 5 & 0.3125 & 5 \\
\hline Antibiotics & & & & & & & & & & \\
\hline Gentamicine 10Ug & $<0.078$ & & $<0.078$ & & 0.156 & & $<0.156$ & & $\mathrm{nt}$ & \\
\hline Ceftazidime $30 \mathrm{Ug}$ & $<0.156$ & & 0.156 & & 0.156 & & $<0.156$ & & nt & \\
\hline Nystatine & nt & & $\mathrm{nt}$ & & nt & & $\mathrm{nt}$ & & $<0.078$ & \\
\hline
\end{tabular}

MIC: Minimum Inhibitory Concentration, MBC: Minimum Bactericidal Concentration, nt: not tested.

\subsection{Molecular Docking Results}

The thymidylate kinase is a key enzyme that is involved in DNA replication and repair mechanisms in most bacterial strains. It catalyzes the phosphorylation of deoxythymidine monophosphate (dTMP) to deoxythymidine diphosphate (dTDP). However, it is necessary to consider this protein in the search for new molecules that avoid the existing resistance mechanisms, as this thymidylate kinase is a new target of anti-S. aureus drugs [13]. The designed molecules $\mathbf{1} \mathbf{b}$ and $\mathbf{5 b}$ could inhibit the ligand-binding-induced receptor, as confirmed by virtual molecular docking using Autodock vina software. The docking scores of the binding affinity $(\Delta \mathrm{G})$ and inhibition constant $(\mathrm{Ki})$ are presented in Table 3 . The molecular docking could confirm the possible binding patterns that may occur with the synthesized compound against the thymidylate kinase protein. Autodock vina scores demonstrate that molecules $\mathbf{1 b}$ and $\mathbf{5 b}$ had significant $\Delta \mathrm{G}$ values of $-8.3(\mathrm{Ki}=0.812 \mu \mathrm{m})$ and $-9.4 \mathrm{Kcal} / \mathrm{Mol}(\mathrm{ki}=0.127 \mu \mathrm{m})$ with $4 \mathrm{QGH}$ binding sites, respectively (Table 3). This interaction affinity is due to the existence of potential H-bond donor and $\mathrm{H}$-bond acceptor groups as well as the hydrophobic interactions with the docked molecules. The $\mathrm{N}-\mathrm{H}$ bonds of the $\mathrm{NH}$ amine and the hydrogen atoms of the hydroxyl group $\mathrm{OH}$ may adopt 
different binding positions, with the active pocket of the protein inducing the receptor inhibition being able to arrest the bacterial DNA replication and reparation mechanisms.

Table 3. Docking scores of $\mathbf{1 b}$ and $\mathbf{5 b}$ on PDB: 4QGH.

\begin{tabular}{cccc}
\hline Protein & Interacting Residue & $\begin{array}{c}\text { Binding Energy, } \\
\Delta \mathrm{G} \mathrm{(Kcal/Mol)}\end{array}$ & $\begin{array}{c}\text { Inhibition Constant, } \\
\text { Ki ( } \mu \mathrm{m})\end{array}$ \\
\hline thymidylate kinase TMK (4QGH) & $\mathbf{1 b}$ & -8.3 & 0.812 \\
\hline & $\mathbf{5 b}$ & -9.4 & 0.127 \\
\hline
\end{tabular}

\section{Conclusions}

Overall, the current study was designed to develop new bioactive drugs. Thus, a set of five new benzimidazole derivatives were synthetized by reacting o-phenylenediamine with several aldehydes and phenolic acids through chemical synthesis and hemi-synthesis using a quick microwave-assisted processes. Hemi-synthesis products were purified using column chromatography and the developed molecules were characterized by ATRFTIR and NMR 1H spectroscopy. All synthetized compounds were screened for their antioxidant and antimicrobial activities using several invitro assays. Among the panel of new benzimidazole derivatives, compound 2-(1H-1,3-benzodiazol-2-yl) phenol (1) b) and 5-(1H-benzimidazol-2-yl) benzene-1,2,3-triol (5b) showed significant potential. Hence, these compounds may serve as lead molecules to develop antimicrobial and antioxidant drugs. Additionally, compounds $\mathbf{1 b}$ and $5 \mathbf{b}$ (2-(1E)-2-phenylethenyl-1H-1,3-benzodiazole) were docked with $S$. aureus thymidylate kinase (TMK) protein (4QGH) using AutoDock Vina software to highlight the structure-activity relationship of these molecules. The results showed an excellent binding score. Further assays should be performed on cytotoxicity as well as in-vivo experimentation to validate their possible introduction into pharmaceutical trials.

Author Contributions: Conceptualization, methodology, software and validation, B.E.C.Z.; formal analysis and investigation, all authors; resources and data curation, all authors; writing-original draft preparation, A.S.; writing-review and editing, S.Z., C.D. and B.E.C.Z.; visualization, C.B.; supervision, B.E.C.Z. All authors have read and agreed to the published version of the manuscript.

Funding: This research has received no external funding and is a part of a Master's thesis research project developed by the first four authors under a research theme of new bioactive molecules for pharmaceutical use.

Acknowledgments: The authors are grateful to the Scientific and Technical Research Centre (CRAPC) of Tipaza, Algeria, for technical support.

Conflicts of Interest: The authors declare that they have no conflicts of interest regarding this manuscript.

\section{Appendix A}

Table A1. GC/MS composition of Cinnamomun verum L. bark strips.

\begin{tabular}{ccc}
\hline Rt (min) & Concentration \% & Compound \\
\hline 4.3 & 0.02 & Tetrachloroethylene \\
8.6 & 0.04 & $\gamma$-Terpinene \\
9.4 & 0.03 & Camphene \\
10.6 & 0.25 & Benzaldehyde \\
14.6 & 0.05 & D-Limonene \\
23.1 & 0.05 & 1,2 -Chromene \\
24.6 & 0.92 & Hydrocinnamaldehyde \\
25.3 & 0.07 & Phenyl 2-Propynyl Ether \\
34.9 & 90.54 & Cinnamaldehyde \\
38.2 & 0.61 & $\alpha$-Cubebene \\
\hline
\end{tabular}




\begin{tabular}{ccc}
\hline 39.1 & 0.06 & Oxirane \\
39.4 & 0.05 & $\alpha$-Copaene \\
39.8 & 0.07 & $(+)$-Sativene \\
40.7 & 0.04 & $(-)$-Isosativene \\
41.3 & 0.05 & $\beta$-Thujene \\
43.2 & 0.03 & Benzenamine \\
43.8 & 2.87 & Coumarin \\
45.0 & 0.21 & Naphthalene \\
46.1 & 0.05 & Amide Hydrocinnamique \\
46.5 & 0.66 & $\alpha$-Cadinene \\
47.9 & 0.90 & -Cadinene \\
48.5 & 0.19 & 1H-3a,7-Methanoazulene \\
49.2 & 1.13 & $4-$ Methoxycinnamaldehyde \\
53.4 & 0.08 & 2,4-Hexadiene \\
55.9 & 0.36 & $\gamma$-Cadinene \\
\hline
\end{tabular}

Table A2. GC/MS composition of Cymbopogon citratus L.

\begin{tabular}{|c|c|c|}
\hline Rt (Min) & $\%$ & Compound \\
\hline 4.6 & 0.02 & Tridodecylamine \\
\hline 7.8 & 0.08 & D-Limonene \\
\hline 12.2 & 4.55 & $\beta$-Myrcene \\
\hline 14.6 & 0.1 & $\alpha$-Limonene \\
\hline 15.4 & 0.31 & $\alpha$-Pinene \\
\hline 16.1 & 0.33 & $\beta$-Ocimene \\
\hline 16.4 & 0.06 & Myrcenylacetat \\
\hline 19.3 & 0.05 & Nortricyclene \\
\hline 19.8 & 0.4 & Furan \\
\hline 20.3 & 1.52 & L-Linalool \\
\hline 21.3 & 0.06 & Fenchol \\
\hline 22.5 & 0.23 & Cyclohexene \\
\hline 23.3 & 0.44 & Trans-Chrysanthemal \\
\hline 23.6 & 0.35 & (R)-(+)-Citronellal \\
\hline 24.5 & 0.81 & Cyclopropene \\
\hline 25.8 & 1.29 & 7-Methyl-1-Nonyne \\
\hline 28.4 & 0.11 & O-Mentha-1(7),8-Dien-3-Ol \\
\hline 30.5 & 34.87 & Neral \\
\hline 32.8 & 43.88 & Cis-Citral \\
\hline 33.7 & 0.32 & Geranial \\
\hline 34.2 & 0.22 & Geranyl Vinyl Ether \\
\hline 35.8 & 3.5 & Geraniol \\
\hline 38.4 & 0.24 & Nerol \\
\hline 39.5 & 3.37 & Nerol Acetate \\
\hline 40.2 & 0.65 & Geranic Acid \\
\hline 41.3 & 0.21 & $\beta$-Caryophyllene \\
\hline 42.4 & 0.17 & $\alpha$-Bergamotene \\
\hline 50.1 & 0.06 & Neryl Acetate \\
\hline 51.4 & 0.08 & $\beta$-Citronellal \\
\hline 54.1 & 0.14 & Trans- $\beta$-Farnesene \\
\hline 70.8 & 0.18 & Farnesyl \\
\hline 72.5 & 0.06 & Trans-Caryophyllene \\
\hline 75.3 & 0.11 & Cyclopropane Carboxamide \\
\hline 76.7 & 0.2 & $\alpha$-Trans-Sequicyclogeraniol \\
\hline 78.3 & 0.31 & Farnesol \\
\hline 79.6 & 0.14 & 3,7-Nonadien-2-Ol \\
\hline 80.0 & 0.07 & Geranylacetone \\
\hline
\end{tabular}




\section{References}

1. Shah, M.S.; Eppinger, M.; Ahmed, S.; Shah, A.A.; Hameed, A.; Hasan, F. Multidrug-resistant diarrheagenic E. coli pathotypes are associated with ready-to-eat salad and vegetables in Pakistan. J. Korean Soc. Appl. Biol. Chem. 2015, 58, 267-273, doi:10.1007/s13765-015-0019-9.

2. Ziani, B.E.C.; Barros, L.; Boumehira, A.Z.; Bachari, K.; Heleno, S.A.; Alves, M.J.; Ferreira, I.C.F.R. Profiling polyphenol composition by HPLC-DAD-ESI/MSn and the antibacterial activity of infusion preparations obtained from four medicinal plants. Food Funct. 2018, 9, 149-159, doi:10.1039/C7FO01315A.

3. Quideau, S.; Deffieux, D.; Douat-casassus, C.; Pouysøgu, L. Natural Products Plant Polyphenols: Chemical Properties, Biological Activities, and Synthesis. Nat. Prod. 2011, 50, 586-621, doi:10.1002/anie.201000044.

4. Dai, J.; Mumper, R.J. Plant Phenolics: Extraction, Analysis and Their Antioxidant and Anticancer Properties. Molecules 2010, 15, 7313-7352, doi:10.3390/molecules15107313.

5. Gyawali, R.; Ibrahim, S.A. Natural products as antimicrobial agents. Food Control 2014, 46, 412-429, doi:10.1016/j.foodcont.2014.05.047.

6. Salahuddin; Shaharyar, M.; Mazumder, A. Benzimidazoles: A biologically active compounds. Arab. J. Chem. 2017, 10, S157-S173, doi:10.1016/j.arabjc.2012.07.017.

7. Chikhale, H.; Nerkar, A. Review on In-Silico techniques an approach to Drug discovery Current. Trends Pharm. Pharm. Chem. 2020, 2, 24-32.

8. Brogi, S.; Ramalho, T.C.; Kuca, K.; Medina-Franco, J.L.; Valko, M. In silico Methods for Drug Design and Discovery. Front. Chem. 2020, 8, 612, doi:10.3389/fchem.2020.00612.

9. Morris, G.M.; Huey, R.; Lindstrom, W.; Sanner, M.F.; Belew, R.K.; Goodsell, D.S.; Olson, A.J. AutoDock4 and AutoDockTools4: Automated Docking with Selective Receptor Flexibility. J. Comput. Chem. 2009, 30, 2785-2791, doi:10.1002/jcc.

10. Trott, O.; Olson, A.J. AutoDock Vina: Improving the speed and accuracy of docking with a new scoring function, efficient optimization, and multithreading. J. Comput. Chem. 2010, 31, 455-461, doi:10.1002/jcc.21334.

11. Rassem, H.H.A.; Nour, A.H.; Yunus, R.M. Techniques for Extraction of Essential Oils from Plants: A Review. Aust. J. Basic Appl. Sci. 2016, 10, 117-127.

12. Ziani, B.E.C.; Calhelha, R.C.; Barreira, J.C.M.; Barros, L.; Hazzit, M.; Ferreira, I.C.F.R. Bioactive properties of medicinal plants from the Algerian flora: Selecting the species with the highest potential in view of application purposes. Ind. Crops Prod. 2015, 77, doi:10.1016/j.indcrop.2015.09.034.

13. Ziani, B.E.C.; Carocho, M.; Abreu, R.M.V.; Bachari, K.; Alves, M.J.; Calhelha, R.C.; Talhi, O.; Barros, L.; Ferreira, I.C.F.R. Phenolic profiling, biological activities and in silico studies of Acacia tortilis (Forssk.) Hayne ssp. raddiana extracts. Food Biosci. 2020, 36, 100616, doi:10.1016/j.fbio.2020.100616.

14. Ziani, B.E.C.; Heleno, S.A.; Bachari, K.; Dias, M.I.; Alves, M.J.; Barros, L.; Ferreira, I.C.F.R. Phenolic compounds characterization by LC-DAD-ESI/MSn and bioactive properties of Thymus algeriensis Boiss. \&amp; Reut. and Ephedra alata Decne. Food Res. Int. 2019, 116, doi:10.1016/j.foodres.2018.08.041.

15. Carocho, M.; Ferreira, I.C.F.R. The Role of Phenolic Compounds in the Fight against Cancer-A Review. Anticancer. Agents Med. Chem. 2013, 13, 1236-1258, doi:10.2174/18715206113139990301.

16. Cushnie, T.P.T.; Lamb, A.J. Agents Recent advances in understanding the antibacterial properties of flavonoids. Int. J. Antimicrob. Agents 2011, 38, 99-107, doi:10.1016/j.ijantimicag.2011.02.014.

17. Borges, A.; Ferreira, C.; Saavedra, M.J.; Simões, M. Antibacterial activity and mode of action of ferulic and gallic acids against pathogenic bacteria. Microb. Drug Resist. 2013, 19, 256-265, doi:10.1089/mdr.2012.0244. 